\title{
PÁGINAS HISTORIOGRÁFICAS NO SÉCULO XIX
}

Germana Maria Araújo Sales*

Resumo: O ensaio apresenta uma discussão acerca da historiografia literária brasileira, levando em consideração a produção publicada em periódicos, durante o século XIX, e não referenciada nas Histórias literárias tradicionais. Para balizar a discussão, o texto retoma as proposições de Machado de Assis, dispostas no artigo "O ideal do crítico" juntamente com as considerações de José de Alencar acerca do gênero romance, estruturadas no prefácio intitulado "Bênção paterna".

Palavras-chave: Historiografia. Século XIX. Periódicos.

5 m 8 de outubro de 1865, quando Machado de Assis publicou, no Diário do Rio de Janeiro, o texto "Ideal do crítico", lia-se a impressão da crítica da época e da situação da produção literária brasileira. Machado afirmava que longos eram os intervalos com que as boas obras apareciam e "raras as publicações seladas por um talento verdadeiro" (ASSIS, 1962a, p. 11-19) e se dirigia a dois aspectos do meio literário que julgava precários, ressaltando, primeiramente, a inexistência de uma crítica séria, livre da camaradagem e envolta na justiça de análise e, em segundo lugar, a ausência de publicações de valor inquestionável.

O que pensaria, atualmente, um aluno do curso de Letras ao se deparar com esse texto crítico machadiano? Considerando-se a autoridade atribuida ao discurso do escritor nos dias atuais, é bem provável que o estudante concordasse com Machado e entendesse que até aquele momento o número de boas obras se contava nos dedos de uma só mão. Caberia, então, ao professor de Literatura esclarecer ao estudante que Machado não estava completamente certo, nem de todo errado, pois suas considerações dependiam da perspectiva a partir da qual concebia o gênero romance, bem como de uma ideia que era senso comum naquele século, qual seja, a de que as boas obras eram poucas. 
Já é sabido que ler romances não dava muita distinção ao leitor do século XIX, como também escrever não elevava rapidamente o escritor à categoria de consagrado, conceito em torno da leitura que provinha de ideias pautadas por alguns eruditos que defendiam como boa leitura aquela que primava pelo afastamento do leitor daquilo que era novo e capaz de permitir a descoberta de uma identidade particular com o texto.

Ao leitor de hoje caberia refletir acerca das afirmações categóricas de Machado, avaliando o momento em que a literatura brasileira se afirmava e quando, particularmente, o romance alcançava sua ascensão em terras nacionais, ponderações suficientes para aquilatar um entendimento contrário ao protesto declarado, principalmente no que se refere à produção de romances.

Nesse contexto, não podemos esquecer que a produção literária brasileira esteve vinculada aos processos políticos que influíram de forma decisiva na institucionalização da literatura nacional. Sabemos que o Brasil sofreu um longo processo de colonização, que acarretou a desvantagem de iniciar as atividades tipográficas somente em 1808, marco que deu início à produção de livros e à circulação de periódicos, favorecendo, dessa forma, o começo da impressão desvinculada da metrópole. Tal fato decisivo possibilitou a expansão intelectual e ampliou a cultura letrada.

Além disso, outro aspecto que viria a corroborar a consolidação das letras em nosso país seria a independência em 1822, acontecimento que contribuiu para a publicação de obras que se ocuparam da construção da identidade nacional e do acréscimo considerável de publicação de romances assinados por autores locais. Tinha início a maturidade das manifestações literárias brasileiras, acontecimento este requerido 43 anos antes do artigo assinado por Machado de Assis, cujo objetivo mais veemente pareceu ser a demanda de uma posição da crítica mais justa e coerente com as regras da arte, bem como obras seladas pelo verdadeiro talento, ponto que nos interessa discutir.

O que vale destacar é que o texto "Ideal do crítico", de Machado de Assis, dialoga com o prólogo "Bênção paterna", assinado por José de Alencar e publicado em 1872 como prólogo do romance Sonhos d'ouro. O romancista dava início ao texto do prefácio advertindo sobre a possibilidade de a crítica não acolher com bons olhos mais um romance, apesar de toda a atmosfera prosaica naquele século:

\section{Ainda romance!}

Com alguma exclamação, nesse teor, hás de ser naturalmente acolhido, pobre livrinho, desde já te previno.

Não faltará quem te acuse de filho de certa musa industrial, que nesse dizer tão novo, por ai anda a fabricar romances e dramas aos feixes.

Musa industrial no Brasil!

Se já houve deidade mitológica, é sem dúvida essa de que tive primeira notícia, lendo um artigo bibliográfico.

Não consta que alguém já vivesse nesta abençoada terra do produto de obras literárias. E nosso atraso provém disso mesmo, e não daquilo que se vai desacreditando de antemão.

Quando as letras forem entre nós uma profissão, talentos que hoje apenas aí buscam passatempo ao espírito convergirão para tão nobre esfera suas poderosas faculdades. 
É nesse tempo que hão de aparecer os verdadeiros intuitos literários; e não hoje em dia, quando o espírito, reclamado pelas preocupações da vida positiva, mal pode, em horas minguadas, babujar na literatura.

Então com certeza se não há de buscar o crítico literário entre os abegões do bezerro de ouro, que passaram a vida a cevá-lo, e com isso cuidam lá no seu besunto que se fizeram barões da imprensa.

[...]

Os críticos, deixa-me prevenir-te, são uma casta de gente, que tem a seu cargo desdizer de tudo neste mundo. O dogma da seita é a contrariedade. Como os antigos sofistas, e os reitores da Meia Idade, seus avoengos, deleitam-se em negar a verdade.

Ao meio-dia contestam o sol; à meia-noite impugnam a escuridão. Como Heráclito, choram quando o mundo ri, ou zombam com Demócrito quando a sociedade se lamenta. Dão-se ares de senado romano, com o afã de levantar uns e abaixar outros: - parcere subjectis et debellare superbos, como disse Virgílio.

Assim, livrinho, um, ao receber-te, talvez se lembre de teres saido de uma cachola, que na véspera não se descobriu amavelmente à sua passagem e não lhe catou a devida cortesia (ALENCAR, s/d, p.VII).

A exclamação que dá início ao prefácio do romance foi dirigida, naturalmente, à "critica sisuda" que, a seu ver, desqualificaria o gênero, tendo em vista os critérios dos avaliadores da época acerca do romance. Seria ainda uma crítica governada pelo ódio, camaradagem ou indiferença, como descreveu Machado em 1865, ou, simplesmente, Alencar se precavia do conceito maledicente em relação àqueles que julgavam sua produção literária atrelada à ganância? Ora, se é um ou outro aspecto sobre o qual se debruça o texto do prólogo, cabe-me refletir sobre quais aspirações teria a crítica oitocentista sobre o romance brasileiro presente nas estantes do período. Dois pontos precisariam ser salientados: a afirmação de Machado de Assis sobre a escassez de boas obras e a prevenção de Alencar diante de mais um romance que viria a lume.

Retomando um pouco a história do romance no Brasil e sua aclimatação enquanto produto nacional, ressaltamos, primeiramente, a situação do gênero de acordo com as histórias literárias quando afirmam, em grande parte, que "no decênio de 1840 apareceu o romance" (CANDIDO, 1999, p. 40). A afirmativa procede se formos estabelecer Teixeira e Sousa e Joaquim Manuel de Macedo como os iniciadores da produção romanesca e reconhecer que os passos iniciais do nosso romance foram tímidos. Contudo, se formos avaliar as particularidades que cercam as produções literárias do século XIX e a generalidade em que estavam envoltos os gêneros no período, não podemos descartar a hipótese de que esse mapa literário começa a ser traçado duas décadas antes de 1840, levando em conta a categoria dos textos em prosa de ficção.

Entretanto, no espaço em que surgiu a prosa de ficção, diversas foram as reações da crítica e dos leitores. A crítica reproduzia o pensamento sobre a forma como os escritos foram recebidos por uma camada de intelectuais e identificava a leitura de romances como moralmente perigosa, comparada às leituras eruditas e religiosas que ampliavam o conhecimento e aperfeiçoavam o espírito, respectivamente. E parece que Alencar tinha razão quando entendia que aqueles a quem era dado o direito de apreciar o romance estavam envoltos pela cortina da contrariedade e tinham a "seu cargo desdizer de tudo neste mundo", 
deleitando-se em negar a verdade, avaliando como boas as obras, somente aquelas, cuja compreensão só era possivel a um determinado grupo restrito.

O desprestígio do gênero foi tanto, que a história tratou de ocultar o início da produção em prosa de ficção no Brasil, assinada por autores nacionais, ocorrido muito antes dos anos 1800, quando alguns se referem à obra As aventuras de Diófanes, de Tereza Margarida da Silva Orta, publicada em 1752 (ABREU, 2004, p. 7), como o primeiro romance brasileiro. Essa assertiva descarta a suposição de que esse mapa literário começa a ser traçado somente na década de 1840, além de contrariar as teses preconizadas até então.

Com efeito, a validade da hipótese de que a circulação de uma ficção nacional anteceda os anos 1840 entra em desacordo com o conceito já internalizado pelas histórias literárias, bem como pela maioria dos artigos acadêmicos divulgados entre professores e alunos.

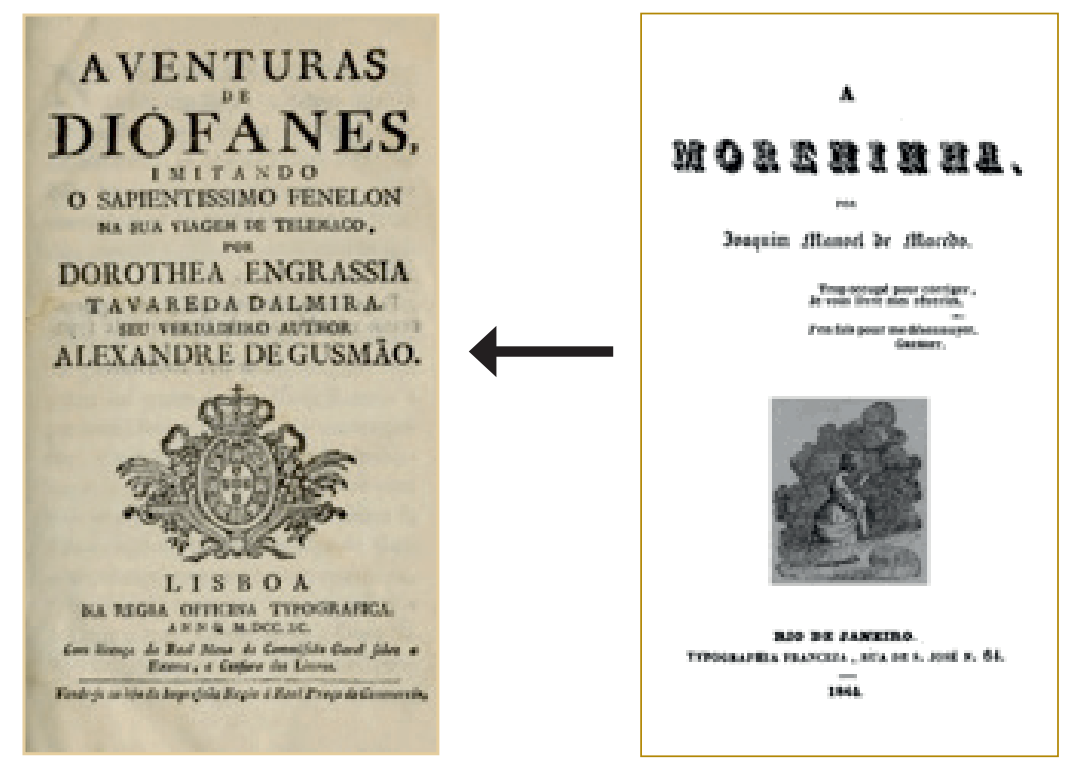

Diante de tantos escaninhos, já se percebe que o professor de Literatura teria um árduo trabalho em situar seu aluno diante de um contexto aparentemente novo. Contudo, se o assunto dessa fala é a defesa da existência de romances, vamos retomar um pouco os acontecimentos literários anteriores a 1843.

É verdade que, antes do decênio de 1840, as obras não estavam dimensionadas no padrão que, tempos depois, as identificaria como romance. Naturalmente, nos anos 1800, o romance já existia, mas era um gênero novo, e a qualificação sobre o que seria novela ou propriamente romance só foi possivel tempos depois. No entanto, seja no formato livro ou em publicações folhetinescas, as manifestações literárias brasileiras em prosa de ficção começaram a aparecer, acanhadamente, em 1826, com a novela Statira, e Zoroastes, de Lucas José d' Alvarenga $^{1}$, acompanhada de outros títulos que circularam entre os leitores

1 Lucas José D' Alvarenga nasceu em Sabará, Minas Gerais, em 1768, e faleceu no Rio de Janeiro, em 7 de junho de 1831. 
anos depois, já na década de 1830, com as obras Januário Garcia ou as sete orelhas (1832), de Joaquim Norberto $^{2}$, A rusga da praia grande ou o quixotismo do general das massas (1834), de Januário da Cunha Barbosa, e os escritos Um primeiro amor e Luisa (1837) e Amor, ciúme e vingança (1838) ${ }^{3}$, assinados por Pereira da Silva 4 .

No final da década de 1830, o jornal aparece como importante meio de divulgação literária e permanece por todo o século XIX como facilitador da relação entre a obra e o público. Nesse contexto, ainda em 1838, o periódico O Chronista publica os escritos Os três desejos e Mariana, de Firmino Rodrigues da Silva ${ }^{5}$ e, em 7 de janeiro desse ano, publica Um sonho, do mesmo autor, no Gabinete de Leitura, com a assinatura "Rodrigues da Silva".
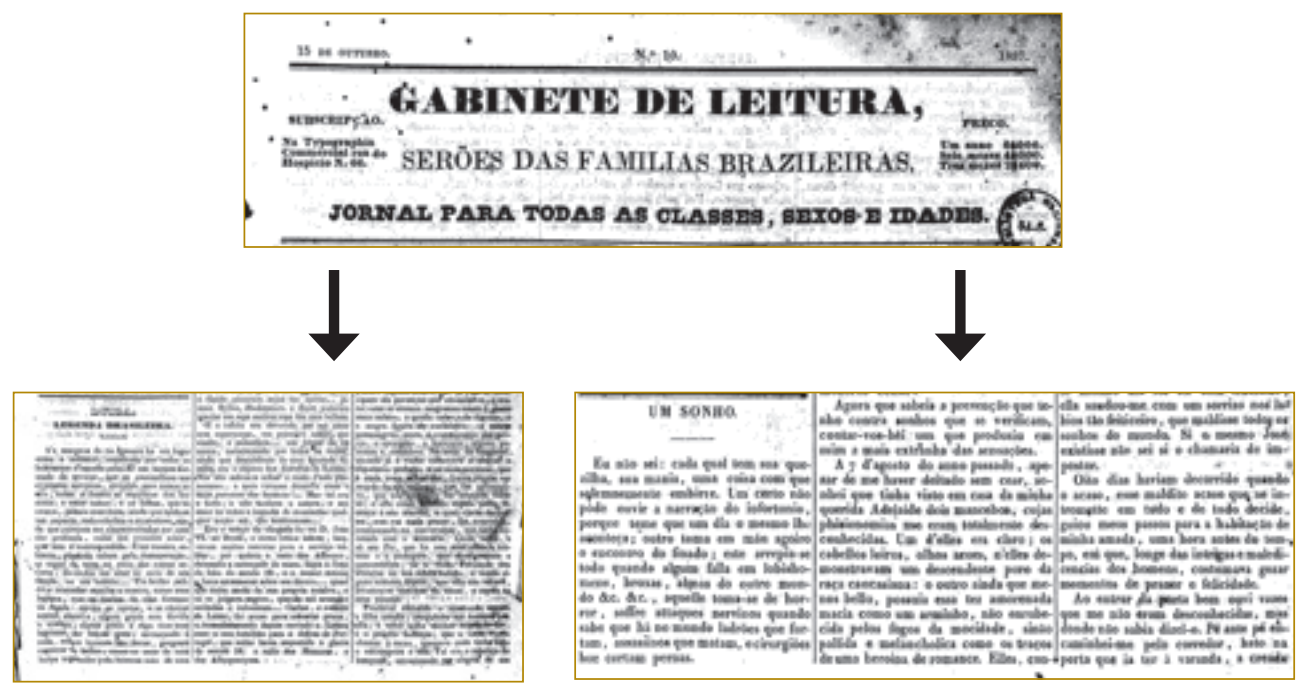

Os títulos, assim como seus autores aqui referidos, não fazem parte da relação conhecida até então por aquele estudante que confia severamente em qualquer texto assinado por Machado de Assis ou José da Alencar, que são autores consagrados e cujas obras até hoje são vendidas e lidas. O desconhecimento do estudante sobre as obras aqui citadas se deve ao discurso de muitos professores e conferencistas que divulgam que o primórdio da narrativa brasileira se deu nos anos 1843/1844. Ao jovem leitor, basta que abra uma História da Literatura e leia com atenção as descrições sobre os acontecimentos literários anteriores às datas estabelecidas. Em alguns casos, ele irá se deparar com certo elogio aos autores aqui referidos e reconhecidos pela sua produção poética, mas considerados péssimos prosadores.

No ano de 1839, o romance-folhetim já está instalado no Brasil, e o Jornal do Comércio é o principal periódico divulgador da novidade. Assumindo toda a for-

2 Joaquim Norberto de Sousa Silva nasceu no Rio de Janeiro, em 1820, e faleceu na mesma cidade, em 1861 (Alfredo Bosi informa a data de 14 de maio de 1891, em Niterói). Segundo José Veríssimo (1915), Norberto foi mais o criador, se não do romance brasileiro, da ficção novelística em prosa.

3 Um primeiro amor, publicado no "Gabinete de Leitura" de 22 de outubro de 1837, com assinatura "Pereira da Silva", e Luísa, publicado no "Gabinete de Leitura" de 22 de outubro de 1837, com assinatura "Pereira da Silva".

4 João Manuel Pereira da Silva nasceu em Iguaçu, Rio de Janeiro, em 30 de agosto de 1817, e faleceu no Rio de Janeiro, em 16 de junho de 1898 (Temístocles Linhares informa Paris o local de falecimento de Pereira da Silva).

5 Firmino Rodrigues da Silva nasceu em Niterói, em 1816, e faleceu em 1879. 
ma afrancesada, incluindo o melodrama e o uso de pseudônimos, Francisco de Paula Brito ${ }^{6}$ publicou naquele periódico, com as iniciais P.B, as obras $A$ revelação póstuma, no dia 9 de março de 1839, A mãe-irmã, em 10 de abril do mesmo ano, e a novela brasileira $O$ enjeitado, também de 1839, nos dias de 28 e 29 de março. Essa última foi editada, posteriormente, pela tipografia do próprio Jornal do Comércio e comercializada pelo preço de 240 réis o exemplar (SALES, 2003). O Jornal do Comércio foi espaço também dos romances históricos de João Manuel Pereira da Silva, O aniversário de d. Miguel, em 1828, Religião, amor e pátria, em 1839, e Jerônimo Corte Real, em 1840.

Além do Jornal do Comércio, outras folhas diárias divulgavam as produções brasileiras, como O Panorama, que publicou, em 1840, a crônica "O descobrimento do Brasil", de Varnhagen 7 , e o Despertador Brasileiro, que publicou as novelas $O$ sedutor e Virginia ou a vingança de Nassau, de João José de Souza e Silva $\mathrm{Rio}^{8}$, também em 1840. Ainda em 1840, mas dessa vez no formato livro, circulou o romance epistolar Heróides de Olimpia e Herculano, jovens brasileiros ou o triunfo conjugal, texto com "nítida mensagem moral e didática" (SERRA, 1997, p. 185), também assinado por João José do Rio.

No período compreendido entre os anos 1840 e início dos anos 1850, a publicação em prosa de ficção brasileira começa a se intensificar com a divulgação de novelas, folhetins e romances. Esse é o momento em que "a influência dos escritores cresce, por meio dos folhetins" (MACHADO, 2001, p. 17), e o comércio de livros no Brasil começa a se desenvolver e consolidar, favorecido, principalmente, pela abertura de diversas tipografias e pela instalação, no ano de 1844, da editora B. L. Garnier.

Na década de 1850 e início dos anos 1860, a literatura se firma e aponta números relevantes para uma produção nacional. Nesse período, nomes como Joaquim Manuel de Macedo, José de Alencar, Bernardo Guimarães, entre outros tantos, ajudavam a construir a desejada literatura genuinamente brasileira.

Entre 1854 e 1863, a prosa de ficção nacional tem finalmente grande representatividade no Brasil, quando são publicadas mais de 100 obras escritas por autores brasileiros, que começam a ser reconhecidos, como Manuel Antônio de Almeida, célebre na história da literatura, com o romance Memórias de um sargento de milicias, publicado primeiramente em folhetim no suplemento Pacotilha do Correio Mercantil, do Rio de Janeiro, em 24 capítulos, entre 27 de junho de 1852 e 31 de julho de 1853, assinado por "Um brasileiro". A edição em livro é do ano de 1854, pela Tipografia Brasiliense de Maximiano Gomes Ribeiro. Além dessas edições, a obra circulou em mais dois periódicos, no Correio Paulistano, em 1856, no Jornal do Pará, em 1857, e na Folha do Norte, em 1898.

Pela única obra, Manuel Antônio de Almeida ficou célebre como um memorialista, dotado de estilo. Contudo, nem todos os autores tiveram o mesmo êxito. Houve alguns casos em que a obra foi publicada em mais de um jornal, além da edição em livro e, atualmente, sequer temos conhecimento dessa publicação. $\mathrm{O}$ paulista de São Roque Antônio Joaquim da Rosa publicou o romance de costu-

6 Francisco de Paula Brito nasceu no Rio de Janeiro, em 2 de dezembro de 1809, e faleceu em 15 de dezembro de 1861, 14 dias após a morte de Teixeira e Souza, de quem sentiu sobremodo a morte e regressou do cemitério já adoentado, conforme descreve Raimundo de Menezes (1978, p. 132), no seu Dicionário literário brasileiro.

7 Francisco Adolfo Varnhagen nasceu em São João de Ipanema, São Paulo, em 17 de fevereiro de 1816, e faleceu em 29 de junhode 1878.

8 João José de Souza e Silva Rio nasceu no Rio de Janeiro, em 4 de julho de 1810, e faleceu em 12 de agosto de 1886. 
mes A assassina, na Revista Literária, a partir do ano I, n. 8, de 14 de novembro de 1850. A edição em livro aparece quatro anos depois pela Tipografia Imp. Constit. De J. Villeneuve \& C, Rio de Janeiro, com 106 páginas e carta prefácio de Júlio Ribeiro (RM). Foi considerado o primeiro romance paulista (JRT, p. 57) e foi republicado em periódico, no Diário Mercantil de São Paulo, entre 2 e 28 de outubro de 1886 (JRT, p. 55). Em 1900, há uma outra edição no formato livro e volta a ser publicado em folhetim pelo jornal Correio Paulistano (JRT, p. 55). A obra circulou em duas edições em livro e três divulgações em periódicos diferenciados, o que totaliza cinco edições só no século XIX.
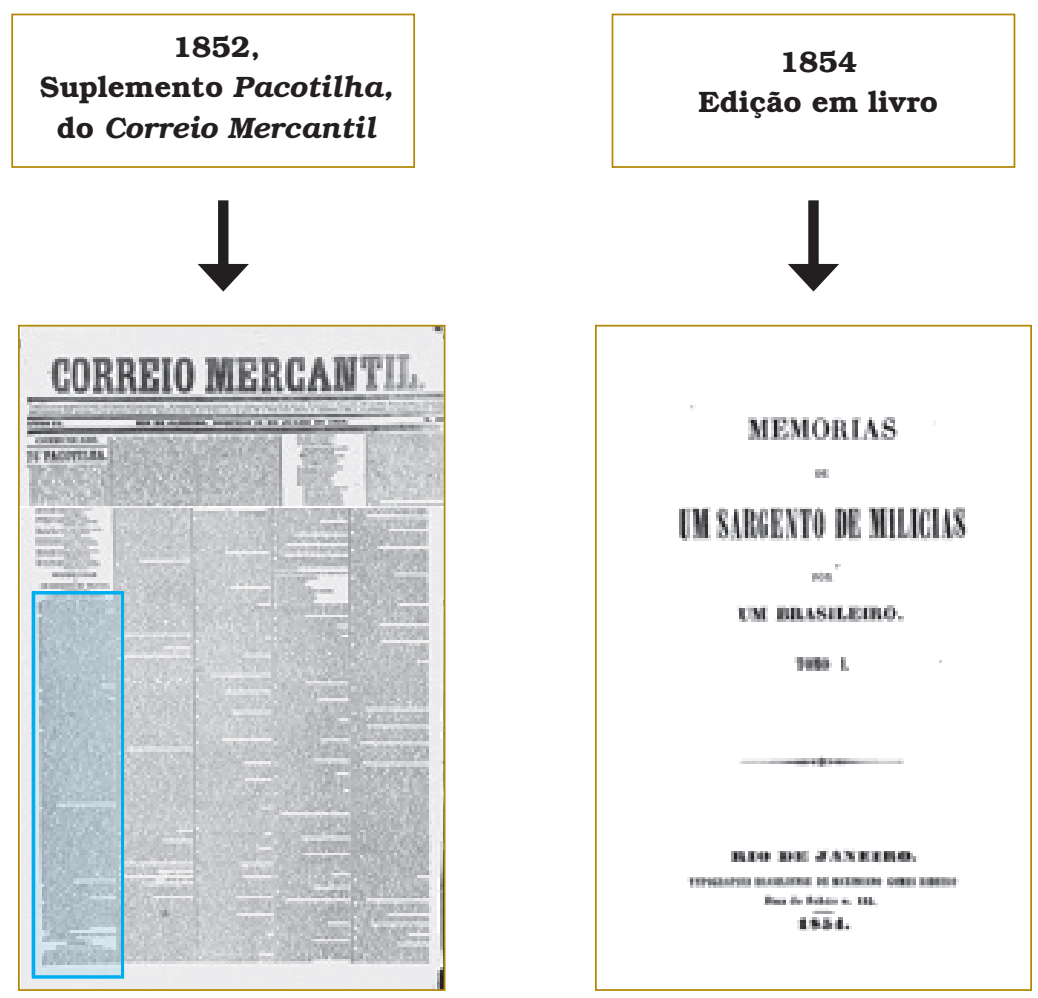


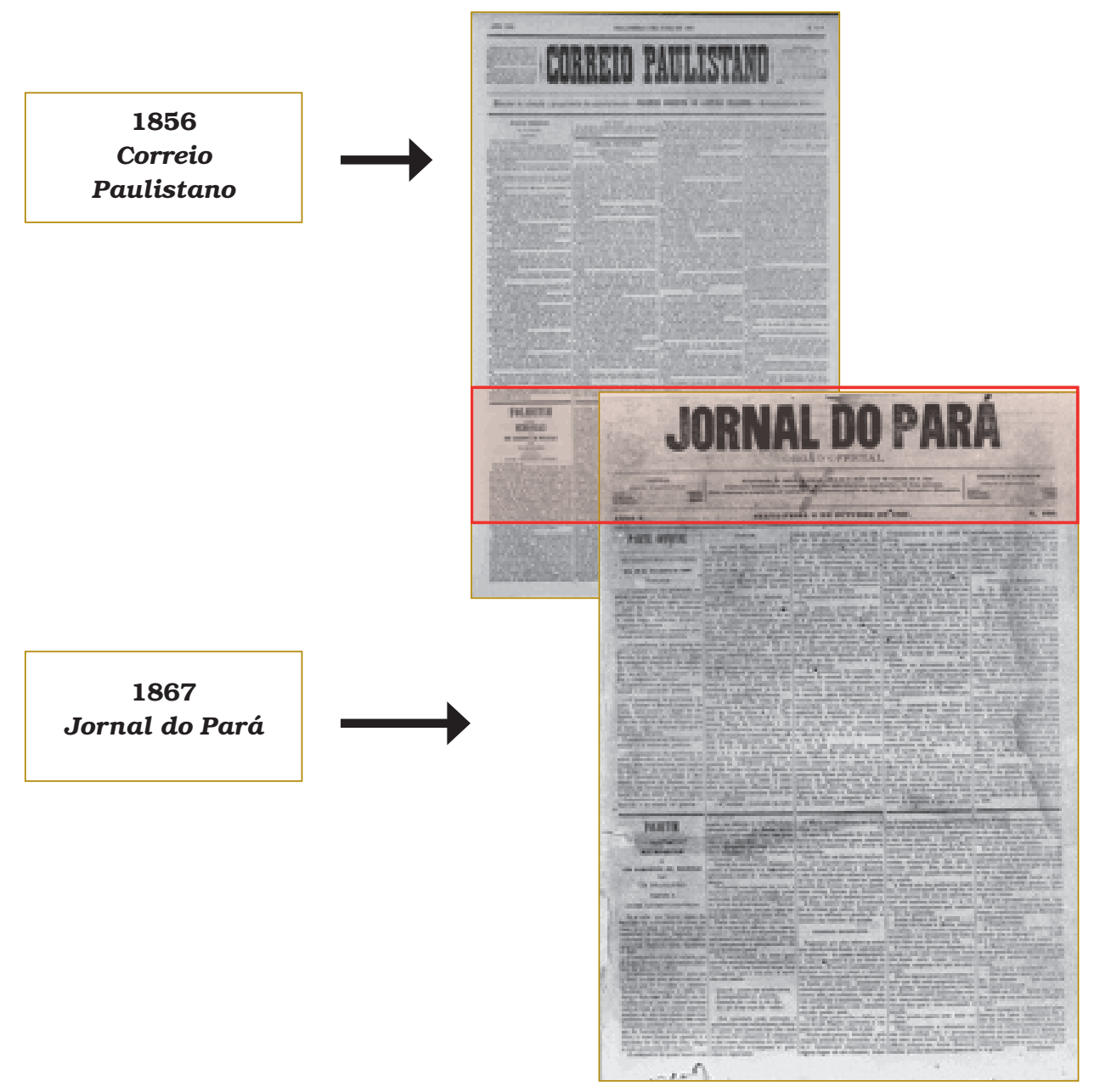

Da mesma forma, Antônio Joaquim da Rosa também publicou A cruz de cedro no Jornal do Comércio, em 1854, e tem edições em livro, no ano de 1900, editado pela Tipografia do Correio Paulistano. A obra conhece outra edição em 1924, pela editora Monteiro Lobato. Após essa presença importante no século XIX, o que sabemos acerca desse autor e sua obra se não tivermos a paciência de percorrer as páginas de um dicionário bibliográfico e descobrirmos que ele é o mesmo Barão de Piratininga? "Depois de passado todo o brilho social, o escritor afundou-se no esquecimento e as várias reedições das obras não foram suficientes para lhe despertar o nome na lembrança da posteridade" (LOPES, 1997, p. 190). Esses são alguns exemplos de obras que sumiram das prateleiras das livrarias ou de qualquer referência historiográfica. 

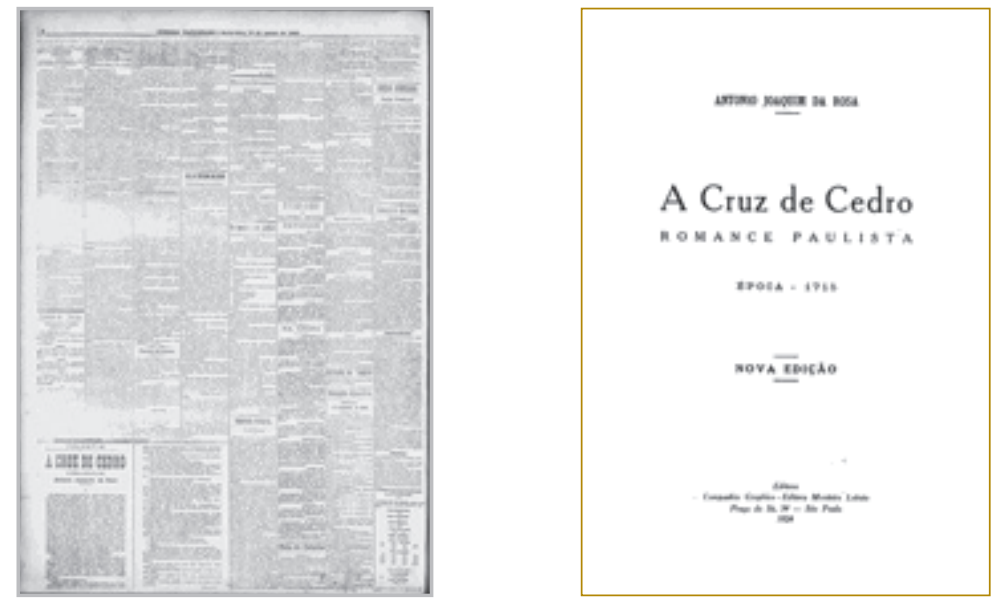

Assim, retomamos nossa discussão inicial, embasada na fala de Machado de Assis, ao lamentar a escassez de obras escritas com talento. Examinando os títulos e os autores referidos, podemos tentar modalizar as afirmações de Machado, uma vez que todos compunham o grupo dos afamados da época.

Ora, sabe-se já que o valor de uma obra não está restrito à literariedade intrínseca ao texto e que a produção escrita e seus autores estão sujeitos a um conjunto de instituições e políticas de avaliação que determinam sua importância. Sabe-se também que, entre as instituições que consagram as obras e seus autores, a crítica ocupa um lugar privilegiado para distinguir a importância dos textos literários, como também é espaço de destaque para aqueles que assinam os ensaios críticos.

A concepção de Machado dirigia-se a duas vertentes: às obras e à crítica, que, segundo ele, era tendenciosa e passional. Essa visão do crítico oitocentista, aparentemente, descreve parte desse conjunto de práticas intelectuais que, ao mesmo tempo, regiam a estrutura que regulamentava o trânsito entre obras e público e materializava a configuração do sistema literário.

Convém lembrar ainda que quando Machado se refere a um século desprovido de obras de valor, justamente no ano de 1865, chegava ao público, além da primeira edição do romance Iracema, de José de Alencar, a segunda edição, em um só volume, dos romances A Viuvinha e Cinco Minutos. Além disso, era publicada também a segunda edição do romance As minas de prata, do mesmo autor. Ainda nesse ano, o leitor conheceu a obra $O$ culto ao dever, de Joaquim Manuel de Macedo, e O ermitão de Muquém, de Bernardo Guimarães, entre outras obras que circularam no período e que dão ideia do volume de produção no século.

Nem sempre era sisudo, porém, o olhar de Machado de Assis diante do panorama literário brasileiro. Em 9 de janeiro de 1866, é publicada, no Diário do Rio de Janeiro, uma apreciação sobre o romance Iracema, de José de Alencar, reconhecendo-o como obra-prima, a despeito da "indiferença pública": 
[...] Há de viver este livro, tem em si as forças que resistem ao tempo, e dão plena fiança do futuro. [...] Que o autor de Iracema não esmoreça, mesmo a despeito da indiferença pública; o seu nome literário escreve-se hoje com letras cintilantes: Mãe, O Guarani, Diva, Lucíola, e tantas outras; o Brasil tem o direito de pedir-lhe que Iracema não seja o ponto final. Espera-se dele outros poemas em prosa. Poema lhe chamamos a este, sem curar de saber se é antes uma lenda, se um romance: o futuro chamar-lhe-á obra-prima (ASSIS, 1962b, p. 73-83).

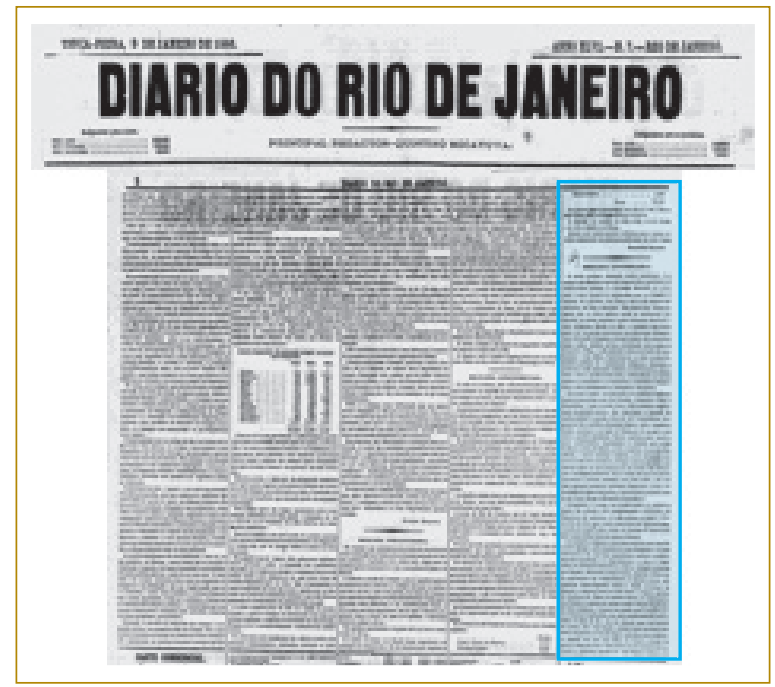

A apreciação de Machado de Assis sobre o romance de Alencar complementa sua ideia de que para julgar uma obra cumpre-lhe "procurar o sentido íntimo" e assim empreender uma análise profunda. Mesmo assim, sua abordagem em relação ao romance do autor cearense não parece resolver o problema sobre o conceito estabelecido naquela época acerca do valor das obras, pois o julgamento esbarrava em, pelo menos, três particularidades - a avaliação interna do texto, as semelhanças que poderia manter com a literatura portuguesa e o não reconhecimento do romance enquanto gênero.

A crítica de Machado demonstra que, mesmo em 1865, o julgamento dos estudiosos deparava-se com as categorias variadas para os textos em prosa e não era de se admirar, portanto, que este ou aquele crítico tivesse dificuldade para classificar os escritos em prosa e julgá-los de qualidade duvidosa se comparados aos demais gêneros já estabelecidos. O romance, por se apresentar contrafeito às regras da retórica e com características amorfas, causava reações da crítica e da camada de intelectuais que se debruçava sobre o assunto.

Trata-se, portanto, de entender que a hipótese existente, nos dias atuais, de que o reconhecimento da obra literária é postulado por uma cadeia de relações institucionalizadas é uma reprodução, em maior escala, do que regia o sistema literário, durante o século XIX. Autores e obras estavam e estão sujeitos a regras e preceitos que não só materializam essas formas literárias como determinam a permanência delas entre os séculos. 
Portanto, sabe-se também que o pensamento avaliativo das obras não obedece a uma regra univoca que defende os mesmos preceitos, nem os constitui como formas históricas subjugadas a uma única legislação. O que convém observar é que o posicionamento de Machado, em 1866, e o de Alencar, em 1875, se coadunam quando identificam a crítica como facciosa, ao ser preparada de acordo com seus gostos, simpatias ou diferentes modelos que tomam como verdadeiro, correndo o risco de desprestigiar outras obras, menos afeitas à individualidade de cada um, e evidenciam que a forma como a história literária se concretiza assume diferentes configurações sujeitas a uma política de leitura, dimensionada, primeiramente, pela crítica, instância capaz de definir as formas de organização do grupo dos seletos.

\section{HistoriograpHIC PAGES FROM THE 19TH CENTURY}

Abstract: This essay presents a discussion about the Brazilian literary historiography taking into account the production that was published in periodicals in the 19th century that were not referred to in the traditional literature's histories. To mark this discussion, the text returns to Machado de Assis' propositions, displaced in the article "The critical's ideal" along with José de Alencar's considerations about the romance genre, structured in the preface entitled.

Keywords: Historiography. 19th century. Periodicals.

\section{REFERÊNCIAS}

ABREU, M. Rumos da ficção no Brasil oitocentista. Revista Moara, Belém, n. 21, 2004.

ALENCAR, J. Bênção paterna. In: ALENCAR, J. Sonhos d'ouro. São Paulo: Edições Melhoramentos, s/d.

ASSIS, M. Ideal do crítico. In: ASSIS, M. Obras completas de Machado de Assis - crítica literária. São Paulo: W. M. Jackson editores, 1962a. v. 29.

ASSIS, M. Iracema por José de Alencar. In: ASSIS, M. Obras completas de Machado de Assis - crítica literária. São Paulo: W. M. Jackson editores, 1962b. v. 29.

CANDIDO, A. Iniciação à literatura brasileira. 3. ed. São Paulo: Humanitas, 1999.

LOPES, H. Letras de Minas e outras histórias. São Paulo: Edusp, 1997.

MACHADO, U. A vida literária no Brasil durante o Romantismo. Rio de Janeiro: UERJ, 2001.

MENEZES, R. de. Dicionário literário brasileiro. 2. ed. Rio de Janeiro: Livros Técnicos e Científicos, 1978.

SALES, G. Palavra e sedução: uma leitura dos prefácios oitocentistas. 2003. Tese (Doutorado em Teoria da História da Literatura)-Universidade Estadual de Campinas, Campinas, 2003.

SERRA, T. Antologia do romance-folhetim (1839-1870). Brasília: Editora UnB, 1997. 
EDIÇÃO ESPECIAL

VERÍSSIMO, J. História da Literatura Brasileira. Rio de Janeiro: Ministério da Cultura; Fundação Biblioteca Nacional; Departamento Nacional do Livro, 1915.

Recebido em setembro de 2016. Aprovado em novembro de 2016. 